\title{
Brucellosis in Colombia: Current Status and Challenges in the Control of an Endemic Disease
}

\author{
Lisa M. Avila-Granados ${ }^{1,2}$, Daniel G. Garcia-Gonzalez ${ }^{1}$, Jorge L. Zambrano-Varon ${ }^{2}$ and \\ Angela M. Arenas-Gamboa ${ }^{1 *}$
}

' Department of Veterinary Pathobiology, College of Veterinary Medicine \& Biomedical Sciences, Texas A\&M University, College Station, TX, United States, ${ }^{2}$ Departamento de Salud Animal, Facultad de Medicina Veterinaria y de Zootecnia, Universidad Nacional de Colombia, Bogota, Colombia

Brucellosis is a zoonosis of nearly worldwide distribution. The disease is considered to be endemic in most of the developing countries with a substantial impact on both human and animal health as well as on the economy. The aim of this scoping review is to provide an overview of the brucellosis status in Colombia and the factors associated with its persistence, to highlight the strengths and gaps of the adopted countermeasures and to supply evidence to policy-makers on the best approaches to mitigate the disease burden. Due to the presence of brucellosis in several susceptible production livestock systems scattered throughout the country, a plan for its control, prevention and eradication was established almost 20 years ago. However, despite extensive efforts, brucellosis prevalence has fluctuated over the years without any trend of decreasing. The restricted budget allocated for brucellosis control is a limiting factor for the success of the program. For instance, the absence of indemnities for farmers results in infected animals remaining on farms which potentially increases the risk of disease spread. Likewise, disease surveillance is restricted to Brucella abortus and excludes other Brucella species of importance, such as B. melitensis and B. suis. The countermeasures are mostly focused on cattle and only a few actions are in place for the management of brucellosis in other livestock species. In humans, cases of brucellosis are annually diagnosed, although the disease remains highly underreported. High impact educational and training programs are required to address the disease in a comprehensive manner, including vulnerable groups, such as traditional smallholders and low-productivity regions, as well as other stakeholders, such as healthcare and veterinary authorities. Important financial investments based on sustained cooperation between governmental institutions, industry, and farmers are important for developing affordable and effective strategies to control the disease.

Keywords: brucellosis, Brucella, Colombia, livestock, zoonoses, public health

\section{INTRODUCTION}

Brucellosis is a zoonotic disease of nearly worldwide distribution, considered to be endemic in the Mediterranean, North and East Africa, the Middle East, South and Central Asia, and Central and South America (1). It is caused by gram-negative bacteria from the genus Brucella. The most common species that affect livestock and humans are B. abortus, B. suis, and B. melitensis, which 
preferentially (but not exclusively) infect cattle, swine, and small ruminants, respectively (2). Other Brucella species include B. ovis (sheep), B. canis (dogs), B. neotomae (rodents), B. microti (voles), B. pinnipedialis (pinnipeds), B. ceti (cetaceans), B. papionis (baboons), B. vulpis (foxes), and B. inopinata, which was isolated from a human breast implant (3).

Abortion and infertility are the most common clinical signs in animals (4). In cattle, brucellosis is associated with abortions during the last trimester of gestation, retained placenta, and weak newborn calves (5). Similar clinical signs occur in small ruminants, although the disease is more severe in goats than in sheep. Mastitis is a common complication in caprine brucellosis. In swine, early fetal loss occurs, and abortion is less common than in cattle. In males, testes and accessory glands are usually affected (6). Contact with infected fetal membranes, aborted fetuses, and uterine secretions allows the dissemination of the pathogen (7). Brucellosis has been recognized as a pathogen in livestock of significant importance. Direct effects include economic losses due to abortion, decreases in milk production, veterinary treatment costs and premature death or culling of infected animals as well as reduced fertility, infection of offspring and transmission to uninfected domestic or wildlife animals. Indirect effects mainly include costs incurred for the implementation of control programs and the forgone revenue due to restricted access to international markets (8).

As a zoonotic disease, brucellosis causes a debilitating illness in humans (9) with significant morbidity in endemic areas (10). The disease is characterized by fever, fatigue, sweats, and malaise. Complications, such as arthritis, endocarditis, and neurological disorders may occur (9). The consumption of raw milk and/or unpasteurized dairy products is the main risk factor for human infections (1). Veterinarians, laboratory workers, livestock keepers, abattoir employees and those associated with animal product industry have a higher risk of acquiring the disease through occupational exposure $(4,5)$. Effects of human brucellosis involve healthcare costs, loss of productive years, physical pain and emotional suffering, which reduce the quality of life for infected people. Moreover, the disease has a negative impact on the overall human population due to loss of livestock production which is a threat to food security (8).

The aim of this scoping review is to provide an overview of the brucellosis status in Colombia and the factors associated with its persistence, to highlight the strengths and gaps of the adopted countermeasures, with the overall goal of supplying evidence to policy-makers on the most suitable approaches to mitigate the disease burden. It is important to note that most of the available data of brucellosis in Colombia is focused on cattle. In other livestock species, few studies have been conducted and limited actions are taken to manage the disease. Consequently, little is known in this field, which represents a limitation of this scoping review.

\section{METHODS}

A literature search was conducted in different databases (Ovid MEDLINE, CAB, Global Health, FSTA, EMBASE, Medic Latina,
Fuente Académica Plus, and Agrícola). The most common terms used in the search strategy were Brucel* ${ }^{*}$ and Colombia. 148 publications were retrieved and those with available abstracts were evaluated. There were no restrictions on language, type of study design or year of publication and, considering the limited information existing, we used broad inclusion criteria (brucellosis in Colombia and prevalence, epidemiology, livestock species, risk factors, economic impact, public health, among others) in our searches. Articles were mainly rejected when (i) they were focused on other countries or diseases and/or (ii) the study population was different from livestock species or humans. Based on these criteria, 27 articles were selected and summarized for data extraction. Due to the heterogeneity of the studies, different aspects were included in the data extraction (e.g., type of study, location, period of study, population, sample size, livestock production system, diagnostic tests and prevalence, main conclusions and additional relevant data). We compared the annual prevalence based on official data, which includes animals from different livestock species distributed in most of the country. We also considered an independent study that tested cattle from all regions following the official established protocols.

Another relevant source of information was the website of the Colombian Agriculture and Livestock Institute (Instituto Colombiano Agropecuario, ICA). Livestock census, regulation of brucellosis, annual reports of the disease among other information were retrieved from this platform. Gray literature was included in our review, due to its importance in identifying and understanding many aspects of the disease in the country. Available data of human brucellosis in Colombia is very limited. Among a few publications found, we included one that collected information from 2000 to 2012 (11). Additionally, a publication about undifferentiated febrile illness was also considered (12).

\section{Colombia and Livestock Systems}

Colombia is a tropical country located in the north of South America. It is bordered by Panama to the northwest, by Venezuela and Brazil to the east and by Ecuador and Peru to the south. The country has a continental land area of $1,141,748$ $\mathrm{km}^{2}$ and is divided into 32 departments and five geographic regions (Caribbean, Pacific, Andean, Orinoquia, and Amazon) based on topography and weather conditions (13). In Colombia, agricultural activities play a significant role in the socioeconomic development of the country (14). The contribution of the agriculture sector to the GDP (Gross Domestic Product) has increased in recent years, from $5.3 \%$ in 2013 to $6.3 \%$ in 2017 (15). In 2018, it was the second economic area of highest growth, despite declines in previous decades. Historically, the agricultural sector contributed up to $20 \%$ to the GDP, highlighting its importance to the nation in the 1980s and 1990s (16).

Livestock species in Colombia include cattle, swine, small ruminants (sheep and goats), and buffalo (Bubalus bubalis), which are distributed throughout the country (Figure 1). According to the national livestock census of 2017 conducted by the Colombian Agriculture and Livestock Institute (Instituto Colombiano Agropecuario, ICA), Colombia contains 23,475,022 bovines, 5,327,460 pigs, 1,140,466 goats, 1,449,705 sheep, and 308,580 buffalo (17). Cattle are the most populous and common 
livestock species (17) and contribute $21.8 \%$ of the total agriculture GDP, and $48.7 \%$ to the livestock GDP (18). Dairy cattle systems are mostly located in the Andean region (19) while Caribbean and Orinoquia regions hold the majority of beef cattle (17). Mixed production systems (dairy and beef) are mostly distributed across the northern and southeastern portions of the country (19). Cattle are reared in pastoral farming and it is estimated that $43.7 \%$ of the producers have $<10$ animals, $37.2 \%$ between 11 and $50,15.9 \%$ between 51 and $500,2.9 \%$ between 500 and 1,000 , and only $0.3 \%$ of the farmers have more than 1,000 animals (20). In dairy cattle systems the average milk production per cow ranges between 12 and $14 \mathrm{~L} /$ day, although some farms produce up to $27 \mathrm{~L} /$ cow daily. Animal density is around $1-2$ cows/hectare, and with $\sim 99,000$ producers, these systems hold $40 \%$ of the milk production of the country $(19,21)$. Double purpose animals are handled by 250,000 farmers, approximately. Although in mixed systems milk production per cow is lower (around 3-5 L/day), these systems denote $60 \%$ of the national production. Milk collection centers process $48 \%$ of the total production, $30 \%$ is used by industry for the elaboration of byproducts, $13 \%$ is sold in farms as raw milk and cheese, and $9 \%$ is intended for calves and family consumption, mainly in small farms (19). Beef cattle production systems comprise about $50 \%$ of the total cattle inventory in Colombia, with an estimated density of 0.6 animals per hectare (20). Around 4.7 million beef cattle belong to feedlot systems, whereas 9.1 million are raised in farms until the last stage (22). Between 2001 and 2010, the bovine population increased by $13.5 \%$. However, adverse climatic conditions negatively affected the productivity and cattle population decreased by $8.3 \%$ from 2010 to 2016 (18). More recently, cattle numbers have begun to recover and increased by $3.5 \%$ from 2016 to $2017(18,23)$.

In addition to cattle, pigs are an important livestock species and are increasingly popular. Between 2005 and 2017, the population of pigs roughly doubled from 2.5 to 5.3 million (24). Pig production is mainly concentrated in the Andean region (17) (Figure 1); the majority (two-thirds) are reared intensively by commercial farms while the remaining third is held by smallscale farmers, having $<10$ sows (24). Small ruminants are the mainstay of income for traditional farms in the Caribbean region $(17,25)$ (Figure 1). Meat is the primary source of income, but other commodities include milk (used for local consumption or cheese elaboration) and wool (sold in artisanal markets). Additionally, trade of live animals can be a source of income to producers (26). Small ruminants are reared in extensive systems, with few exceptions of semi-intensive systems (25). Populations of small ruminants saw a 9.8\% decline from 2009 to $2015(26,27)$, but numbers have rebounded (6.2\% growth) between 2015 and 2017 (17, 27). Buffalo were introduced to Colombia in 1960 (28) and are mainly located in the Caribbean and Andean regions (Figure 1). Buffalo production has increased 19.3\% between 2016 and $2017(17,23)$ and is rapidly becoming an important livestock species due to its adaptability to tropical conditions and the economic benefits of meat and milk production $(28,29)$.

Mixed extensive livestock systems are common in the country and belong mainly to smallholders, who use part of their production for self-consumption and contributing to their livelihood (30). These family livestock systems play a major role in sustained rural development and account for up to $80 \%$ of the farms in the country (31).

\section{Status and Current Management of Brucellosis}

In Colombia, brucellosis was first serologically diagnosed in 1924, and was isolated for the first time in 1927 (32). Outbreaks in herds have been reported for almost a century (33). The only recognized Brucella species in livestock is B. abortus (biovars 1,2, and 4) (34). The other only known strain to be present in the country is $B$. canis, which infects dogs (35). Interestingly, despite the increase in population of other livestock species, such as swine and small ruminants, there have been no reports of B. suis or B. melitensis in Colombian livestock (36). This is probably due to the small number of pigs, sheep and goats that are tested and then only for B. abortus (37).

Acknowledging the endemic status of the disease, in 2002, the ICA decided to implement a national program for the control, prevention, and eradication of brucellosis in cattle, buffalo, goats, sheep, swine, and equids (37). The countermeasures listed in the plan include: (1) mandatory immunization of bovine and bubaline females, (2) mandatory notification of suspected and positive animals, (3) epidemiological surveillance, and 4) control of animal movement. The live attenuated vaccines strain 19 (S19) and strain RB51 are the officially approved vaccines in Colombia for the control of bovine brucellosis. Vaccination using one of these strains is mandatory for all bovine and bubaline females aged between 3 and 8 months (37). In 1999, almost 30 years after the beginning of vaccination with S19, the RB51 vaccine was introduced into the country (38) due to its DIVA (differentiating infected from vaccinated animals) capabilities (39). However, this vaccine is more expensive than S19, and its efficacy has been shown to be lower $(3,40-42)$. Therefore, females immunized with RB51 must be booster-vaccinated with the same strain between 13 and 18 months. In Colombia, this revaccination is optional in animals immunized with S19 (37), an adopted practice that is not stipulated under the World Organisation for Animal Health (OIE) guidelines (43). Booster-vaccination should be done only with RB51 vaccine in non-pregnant females older than 5 years of age and thereafter, every 5 years. Vaccination is carried out during two specific periods per year as established by the ICA. If some animals do not meet the vaccination requirements during these cycles, farmers can request a permit to immunize them outside of these periods which is called "strategic vaccination" and is only done by authorized veterinarians (37). Vaccination with S19 is subsidized by the Colombian Federation of Cattle Producers (FEDEGAN). In contrast, expenses of vaccination with RB51 are completely covered by cattle owners (44) which is around US $\$ 1.55$ per animal.

As member country of the OIE (45), Colombia follows their list of notifiable terrestrial and aquatic animal diseases (46). Therefore, clinically suspected brucellosis cases are reported to the local veterinary authority (45) which confirms suspected cases by using approved diagnostic tests (37). Unfortunately, due to the absence of specific clinical signs, lack of awareness, and similarity 


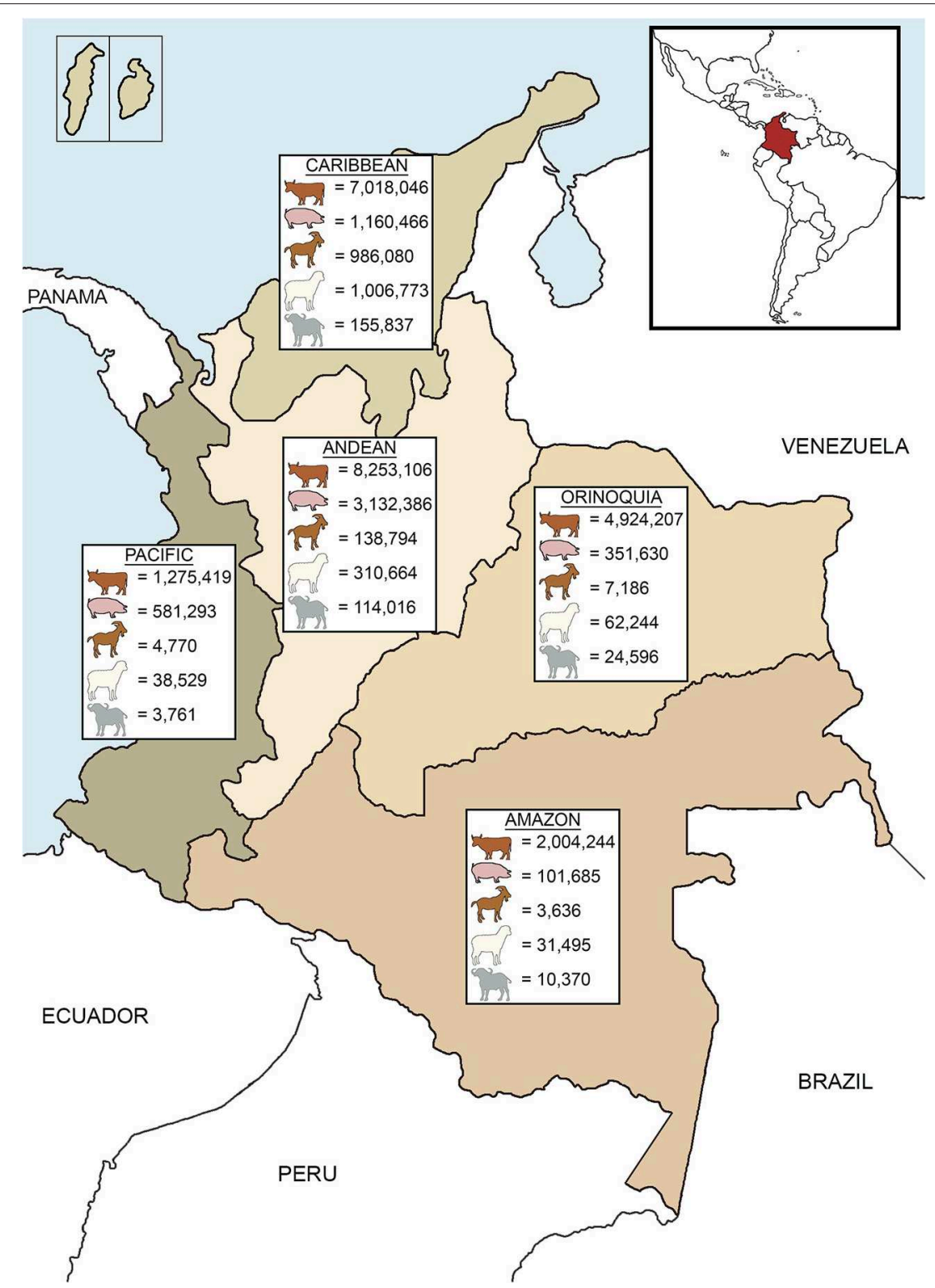

FIGURE 1 | Livestock distribution according to the geographic regions of Colombia. Livestock populations are based on official data of the national census in 2017 (17).

to other endemic diseases that cause reproductive failure, farmers tend to self-medicate resulting in underreporting of brucellosis $(47,48)$. As a solution to improve diagnostic availability, the socalled "Authorized Inspection Organisms" were created, which are private entities across the country, where specific laboratories and trained veterinarians are added to a list of authorized individuals and entities which are approved to diagnose the disease $(13,49)$. Unfortunately, the low income of many smallfarmers and the relatively high costs of the assays do not allow for the testing of many clinically suspected animals, contributing to the underestimation of the disease.

On farm detection involves the use of a screening test, followed by a confirmatory test. Testing is mandatory for international trade, animal movements inside the country and for clinically suspected animals $(37,45,50)$. Two protocols are officially approved for the diagnosis of $B$. abortus in bovine and bubaline females older than 24 months and bulls older than 8 months. The first approach utilizes the Rose Bengal Plate Test (RBPT) or Indirect ELISA (except in buffalo and bovine immunized with S19 and booster-vaccinated with RB51) as a screening test, followed by Fluorescence Polarized Assay test (FPA) as a first confirmatory and Competitive ELISA as a second confirmatory approach. The second method utilizes FPA as a screening test and Competitive ELISA as a confirmatory test (37). Swine, sheep, and goats older than 6 months are only tested for B. abortus with RBPT as a screening test and Competitive ELISA 
as a confirmatory test (37). There is no official surveillance for B. melitensis and B. suis, highlighting a significant gap in the disease surveillance. Consequently, the lack of an appropriate epidemiologic surveillance strategy for other Brucella species cannot truly confirm the claimed "free status of B. melitensis and B. suis" for the country. Microbiological culture and molecular detection methods are not used routinely (37) due to the lack of laboratory facilities to perform these assays, posing a significant impediment. Producers must slaughter animals confirmed to be positive without receiving any indemnity. The only exception was in 2012, when US\$2.0 million were allocated to compensate cattle owners for slaughtering test-positive animals. However, this budget only allowed the slaughtering of 13,249 animals (cattle and buffalo) from more than 70,000 positive reactors during that year $(51,52)$. Usually, farmers are not compensated (13) and consequently, many producers who are not willing to sacrifice their animals do not test clinically suspected cattle, failing to remove positive animals (48). In fact, the lowest percentage of cattle tested annually corresponds to those with suspected clinical signs (Figure 2) (36, 51, 53-61). These animals may be empirically treated with antibiotics, illegally displaced to other farms, or sacrificed in non-authorized slaughterhouses, perpetuating the disease.

As part of epidemiological surveillance, a program to certify farms free of brucellosis was established, and since 2009, this program covers most of the cattle tested annually (Figure 2) $(36,51,53,58-61)$. Farms are certified when $100 \%$ of the animals are found to be negative for $B$. abortus after being tested twice in an interval of 6 months. To maintain this status, a re-certification is done after 1 year and thereafter, every 2 years. For this recertification, animals are randomly tested, and the sample size depends on the number of animals that meet the sampling age in the farm (e.g., <16: all, 101-150: 66, > 1,000: 100), except in dairy farms, where all animals are tested. If a farm has positive animals during the certification or re-certification, positive reactors are sacrificed, the farm is placed under quarantine and animals from neighboring farms are tested, which is known as "sanitation" (37). However, the costs associated with this program (e.g., test and slaughter without compensation) is a limiting factor for many producers. Therefore, participation in the program is voluntary and the monetary incentive consists of an increase in the price of milk sold by the farm (US $\$ 0.0032$ per liter of milk) if they are declared negative to brucellosis (62). Beef operations do not have any incentive. This explains why most of the participants in the program are dairy cattle and double purpose farms, while participation by beef cattle systems is very limited (13). In fact, in regions were beef cattle are predominant, surveillance activities are lower than in those that hold mainly dairy cattle (63). The number of active farms in the brucellosis free program has declined significantly in recent years, from 20,932 farms in 2015 to only 15,676 farms in 2018 (52). The current estimated number of cattle farms in Colombia is about 514,000 (17) which means that the program has successfully certified $<4 \%$ of the herds (52). Since 2013, active surveillance is carried out in cattle, although during that year, it represented only $1.2 \%$ of the total cattle tested (61). However, these activities have been slowly increasing, and in $2015,3.4 \%$ of the testing in this species corresponded to active surveillance (Figure 2) (36).

Livestock movements within the country are only authorized if animals are serologically negative to brucellosis (64). Brucellosis-free farms can move their animals without restriction. In contrast, farms positive for brucellosis or those with unknown disease status are only able to move animals if they have a negative serological test issued up to 30 days prior to movement (37). During 2005 and 2008, up to 50\% of the total cattle tested corresponded to animal movements, and more than 110,000 animals were tested annually during those years (54-57). More recently, these numbers have declined, and in 2015 , only 23,133 cattle were tested for this activity, which represented $5.9 \%$ of the total cattle tested that year (Figure 2) (36). Legally imported livestock are clinically examined at all entry points. If their entry into the country is authorized, animals

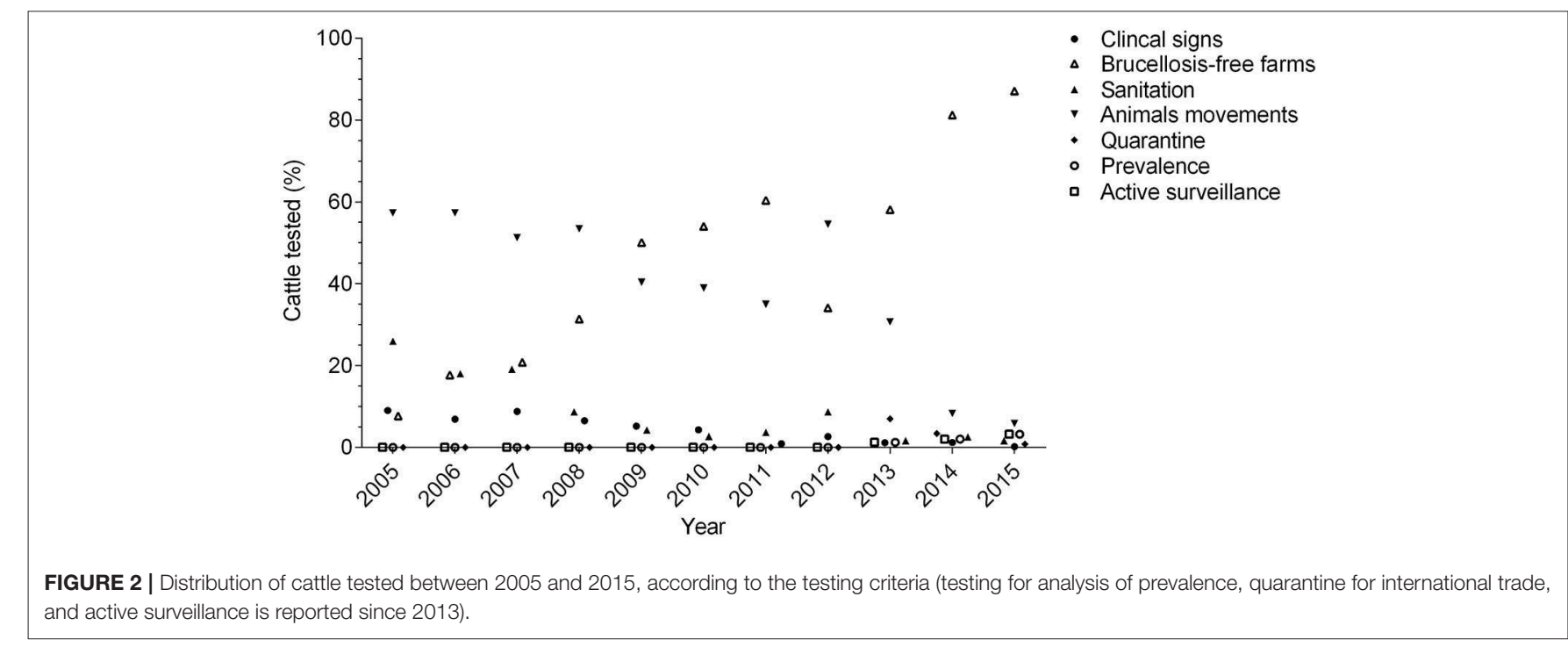


TABLE 1 | Number of animals tested (cattle, sheep, goats, swine, and buffalo) and percentage of seropositivity between 2005 and 2015 .

\begin{tabular}{lcc}
\hline Year & Animals tested & Seropositivity (\%) \\
\hline 2005 & 199,429 & 5.2 \\
2006 & 232,426 & 4.7 \\
2007 & 242,013 & 4.6 \\
2008 & 307,784 & 4.3 \\
2009 & 779,105 & 2.8 \\
2010 & 427,873 & 5.7 \\
2011 & 561,904 & 6.1 \\
2012 & $1,528,324$ & 4.6 \\
2013 & 763,707 & 3.2 \\
2014 & 338,651 & 4.2 \\
2015 & 404,243 & 3.4 \\
\hline
\end{tabular}

are placed in quarantine zones where they undergo laboratory tests to confirm their health status. Only after being found free of infectious diseases, including brucellosis, are animals allowed to be moved to their final destinations (50). It is well-known that non-regulated animal trade has important implications in the dissemination of brucellosis (65). However, despite legislation, illegal animal movement occurs inside the country, although the exact numbers are unknown (63). Illicit importation of animals that do not meet entry requirements is a current concern. In fact, smuggling of cattle from Venezuela has become very cost-effective due to the devaluation of its national currency, which allows the purchase of Venezuelan livestock at low prices for a profitable sale in Colombia (66). Between 2016 and 2018, $\sim 4$ million cattle were introduced into the country (67), and according to official data, the number of mobilized cattle exceeds the total number of animals legally registered with the ICA, especially in regions bordering Venezuela (68).

Brucellosis prevalence, as measured by confirmatory serological assays, and the number of animals tested (cattle, sheep, goats, swine, and buffalo) has fluctuated over the years, and a clear trend has not emerged from the data (Table 1). Between 2005 and 2015, the sample size as well as the test and cull programs were affected by climate-related emergencies $(13,36,51,53-61)$. Therefore, the serological data should be interpreted cautiously because these variations in sample size can influence the seropositivity.

Cattle have strongly influenced the livestock seropositivity to brucellosis, due to its high contribution (up to 98\%) in the numbers of animals tested annually $(36,51,53-61)$. In $2005,10 \%$ of the cattle tested were positive (57). Between 2006 and 2015, the sample prevalence remained between $2.8-6.1 \%$ (Figure 3). During those years, annual fluctuations in the herdlevel prevalence of brucellosis were recorded (15-28\%) $(36,51$, 53-61). Since 2013, the ICA has begun to report population prevalence estimates. However, these estimates are derived from disproportionately small sample sizes, comparatively with the population size $(36,60,61)$. A recent study, which evaluated 5,215 cattle, found a seroprevalence of $1.5 \%$ (69). This study calculated the sample size to be representative for each region;

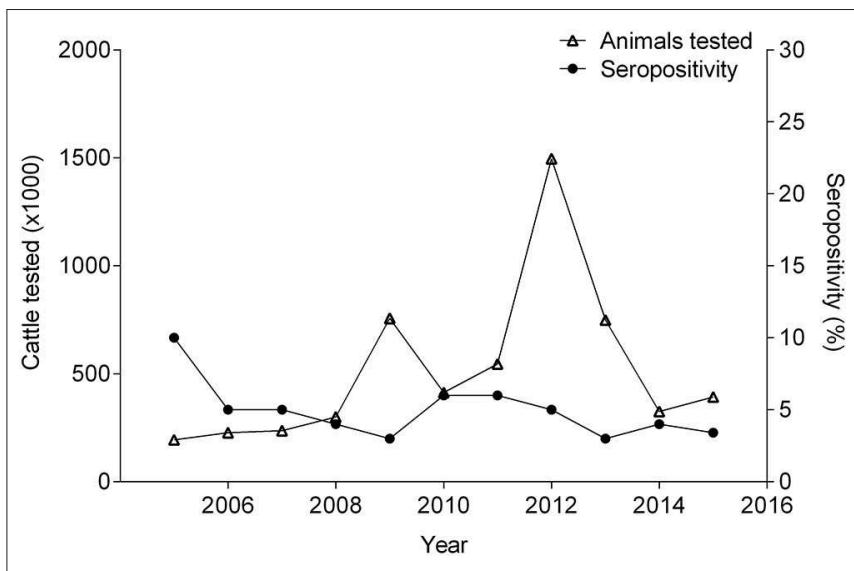

FIGURE 3 | Number of cattle tested and percentage of seropositivity between 2005 and 2015.

however, as well as the ICA, the study tested both dairy and beef operations without considering differences in herd management like biosafety practices, herd density, and geographical conditions that can affect transmission risks; which is a limitation. Therefore, different epidemiological surveillance approaches are needed to identify risk factors for both dairy and beef operations in order to effectively manage brucellosis in these populations. Furthermore, this study exposed the difficulty of applying the FPA as a brucellosis screening tool because if the cut-off value is not determine carefully, then, the test will not be able to differentiate between animals vaccinated with S19 versus those that had been exposed to a wild-type strain (69). In 2018, the Department of Antioquia (northeast of the country) declared an outbreak of brucellosis (mainly in dairy cattle) (70), and speculated that factors, such as vaccination failures and unrestricted movement of cattle from other regions were responsible. Notwithstanding these contingencies, it is also possible that because the cut-off value was arbitrarily lowered in the confirmatory test, more animals were considered positive. More science-based evidence is needed to validate the accuracy of the new cut-off value. Unfortunately, an epidemiologic study has not been published, and the region remains under quarantine (70).

Between 2005 and 2015, seropositivity in sheep increased from 0 to $5.5 \%$, while the number of sheep tested increased by 22 fold. During this time period, in the goat population, sample size, and seroprevalence also varied (Figure 4). Concurrently, pigs experienced variation in seropositivity and sample size along with buffalo (Figure 5) (36, 51, 53-61). There was not a correlation between the seropositivity, and the animals tested.

Few small-scale serological studies of brucellosis prevalence have been conducted in Colombian livestock (Table 2). The reported seroprevalences in cattle have ranged between 0.6 and $6.3 \%$ at individual level, and $12.7-40 \%$ at herd-level $(71-80)$. In buffalo, two different studies assessed the seroprevalence of brucellosis by RBTP and Competitive ELISA, finding a higher seropositivity in buffalo from the Amazon region, than in those reared in the Caribbean region (11.9 and 3\%, respectively) (29, $80)$. It is hazardous to state a conclusion from these studies, due 

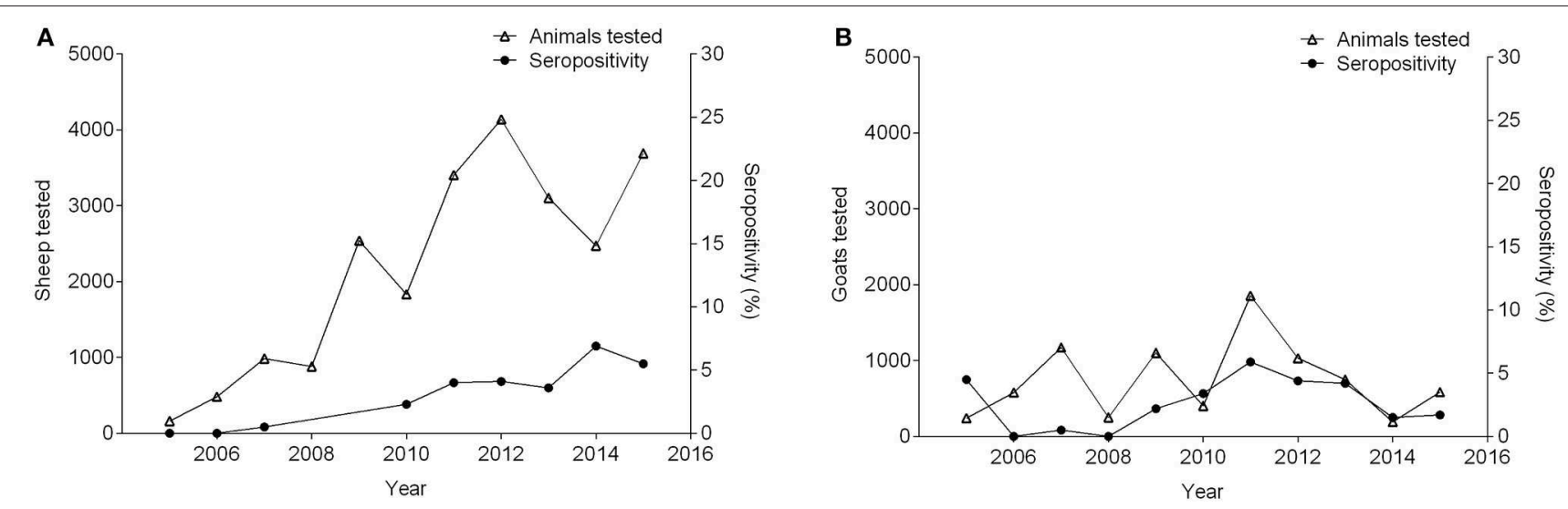

FIGURE 4 | Number of small ruminants tested and percentage of seropositivity between 2005 and 2015. (A) Sheep (seropositivity not available in 2008 and 2009 ), (B) Goats.


FIGURE 5 | Number of pigs (A) and buffalo (B) tested and percentage of seropositivity between 2005 and 2015.

to the heterogenicity in their conditions. Only one study has been conducted to assess the status of $B$. melitensis in small ruminants, which did not identify positive reactors (81). Likewise, the only study conducted in pigs to evaluate the presence of $B$. suis, established $0 \%$ of seropositivity (82). This evidence shows that most of the investigations have been focused on cattle, leading to a paucity of research in other livestock species and other Brucella species than B. abortus.

\section{Public Health Relevance}

Brucellosis is one of the most important zoonoses in Latin America (83), and human cases of the disease have been reported in Colombia over the years (11). Despite its known high prevalence in animals (63), in 2015, only 656 serum samples from suspected human cases were tested. An alarming seropositivity rate of $3.8 \%$ was discovered (36). Unfortunately, the sources of infection could not be determined due to gaps in the recorded data $(11,36)$. Traditionally, the consumption of raw milk and/or its by-products, as well as contact with infected animal tissues and secretions, are considered the main sources for human infection (1). In many regions of the country, artisanal cheese elaboration for local consumption is done without milk pasteurization $(19,26)$. Non-specific symptoms coupled with a long list of differential diagnoses make human brucellosis a highly underreported disease (2). In fact, with the emergence and re-emergence of febrile illnesses, such as dengue, Chikungunya, yellow fever, Zika virus infection, and Venezuelan equine encephalitis, among others (which share clinical signs with brucellosis), such diseases are usually the main differential diagnoses for febrile illnesses, leaving brucellosis highly underdiagnosed $(2,12)$. In Colombia, human brucellosis is a clear example of a neglected disease. Despite its public health significance, the establishment of an adequate surveillance system is currently lacking (84). Therefore, it is imperative that a strategy be developed that involves public awareness for consumers and human health workers coupled with enhanced laboratory diagnostic capacity and enhanced surveillance systems for disease recognition.

\section{Current Challenges}

Despite the countermeasures adopted by local authorities 20 years ago, brucellosis is still prevalent (63), and the control of 
TABLE 2 | Studies of brucellosis seroprevalence in Colombian livestock.

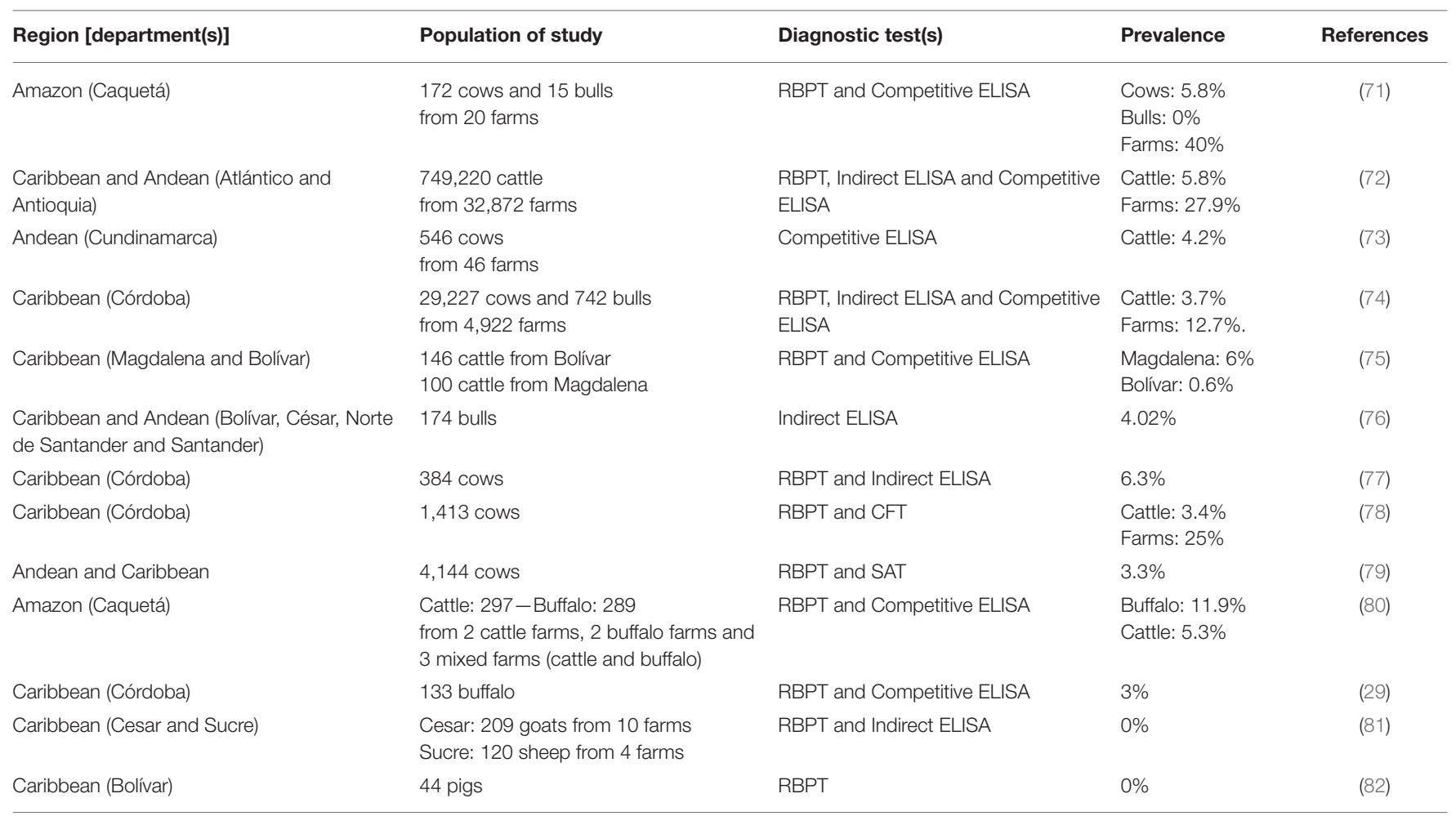

The studies were summarized according to the region of study, the population tested, the diagnostic tests used and the calculated prevalence (\%).

RBPT, Rose Bengal Plate Test; CFT, Complement Fixation Test.

the disease represents a challenge for veterinarians and public health authorities. The difficult diagnosis based on clinical signs (2) and the lack of indemnities for test-and-slaughter (13) make brucellosis an underreported disease in livestock. In humans, the underdiagnosis is attributable to the lack of awareness to consider brucellosis in the list of differential diagnoses of febrile illnesses (85). Current issues associated with the limited epidemiologic studies and surveillance strategies for B. melitensis and B. suis are also of important concern due to the remergence of these pathogens in South America (81).

There is a direct association between the financial resources of countries and their brucellosis status. The lack of funding allocated for brucellosis programs in developing countries does not allow the execution of strict and effective measures (47). This is important in Colombia, where the decline of the agricultural contribution to the GDP and the growth of other economic activities during the last decades have led to a reduction of public investments into this sector. In addition, the armed conflict that forced the migration of communities from rural areas, the lack of public policies benefiting small and mediumsized farmers, and the establishment of Free Trade Agreements (FTA) not favoring local production, have hindered agricultural activities $(14,86,87)$. Poverty in rural areas is a significant barrier to control the disease (85). For instance, when producers are unable to pay for diagnostic testing and slaughtering of positive animals without indemnity, their participation in the program for brucellosis-free farms is not feasible. It is necessary to understand the different socio-economic conditions in the production systems, to design affordable measures and policies for all the producers (20). Budgetary constraints restrain compensations and financing for diagnostic tests, leading to deficiencies in epidemiologic surveillance, and revealing the economic weakness of the program (47). This aspect is relevant due to the fact that effective surveillance must be the strongest component to manage the disease, as it identifies the infected populations, quantifies the disease burden, and directs authorities to the best corrective actions (88). In fact, when extra funding was allocated to the program to compensate cattle owners for slaughtering test-positive animals, surveillance activities improved, and the numbers of animals tested increased from 561,904 in 2011 to $1,528,324$ in $2012(51,58)$. Since the beginning of the program, several adjustments have been implemented probably due to budget limitations for the adoption of suitable measures and to errors in the formulation of adequate policies $(37,47,89-$ 92). In fact, the exclusive surveillance for $B$. abortus even in animals which are mainly affected by other Brucella species is an example of these controversial strategies. It seems that the current program has lost confidence and popularity due to the lack of incentives for producers, the slow response of the diagnostic laboratory system, and the uncertainty of properly differentiating between a seropositive herd and a truly infected herd.

According to official data, vaccination coverage has been increasing and, currently, $\sim 98 \%$ of bovine and bubaline female 
populations are immunized (93). Despite this apparent high coverage, brucellosis prevalence has not had a significant decline (63), a situation that may be linked to the persistence of infected animals on farms, vaccination failure and/or the unfamiliarity of the real prevalence due to the fluctuation in the number of animals tested per year and possible errors in the interpretation of diagnostic tests. The illegal movement of animals is also relevant in the maintenance of brucellosis (94) since these animals do not meet the health requirements (including vaccination, which means that the coverage could be overestimated), representing a constant threat of introducing the disease (95). Increased surveillance for these activities is required, as well as the implementation of legal penalties imposed on those who participate in illegal trade of animals into the country (48). In addition, it is necessary to enforce restrictions of animal trade; but more relevant, to educate farmers in good agricultural practices to avoid common risk factors, such as the introduction of new animals with unknown sanitary status to livestock systems or the exchange of bulls among neighboring farms (94).

According to data recorded from 25 small and mediumsized farms located in the Andean region, economic losses in milk production ranged between US $\$ 588$ and US $\$ 772$ per cow/year, and one infected cow could represent US \$2,412 of lost income annually when other parameters were considered (96). The decrease in milk production due to common events like infertility and abortion motivates dairy cattle farmers to support the control of the disease. The extra revenue of milk sold by brucellosis-free farms is also an incentive for their participation (94). In contrast, the restricted knowledge of beef cattle owners about brucellosis, the lack of economic studies, and the absence of financial incentives in these production systems, limit the awareness of the negative impact of the disease as well as any interest to participate in the program (94). The participation of livestock producers in the development and implementation of strategies has been an essential factor in countries where the disease has been successfully controlled (88). Considering that economic incentives increase the involvement of farmers in the control of brucellosis, an active role of industry is critical at this point (85). The development of strategies by public-private partnerships may generate financial sources for the program, allowing a better coverage in terms of financial incentives for producers. Educational strategies for community empowerment and the development of locally basedorganizations facilitate the participation of the farmers in the brucellosis program and in generating funding sources for its sustainability $(97,98)$.

High impact educational and training programs must be focused on all socio-economic levels and livestock systems, including vulnerable groups, such as traditional smallholders and low-productivity regions, where surveillance activities are limited (13). These public awareness campaigns should be tailored to educate consumers and farmers of the risks associated with the consumption of raw milk or its dairy products, and the advantages of reducing the disease burden on farms (48). An active role of healthcare authorities, including qualified professionals in the control and prevention of zoonoses, will lead to a better diagnosis of brucellosis in humans as well as a better understanding of the disease dynamics in affected populations (85). Human morbidity is significant in areas where brucellosis is endemic (10), and the management of the disease in animals represents the best approach to decrease the rate of infection in people (99). Therefore, the development of an effective program with affordable strategies for all livestock owners will contribute to the welfare of communities (96). To effectively increase the impact of the current program, an epidemiologic assessment of the countermeasures in place is necessary. Other strategies include the implementation of differential surveillance strategies for the different production systems, the identification of highrisk areas, and the identification of truly infected farms, which implies a robust laboratory system. Scientific reviews of the efficiency and interpretation of the serologic tests and their cutoff, as well as the further effect of S19 and RB51 vaccination on the results of these assays are also required. Concerted and participatory efforts are critical to perceive the cost-benefit of the program, including important financial investments and sustained cooperation between governmental institutions, industry, and farmers (47).

In spite of a national brucellosis control program, the prevalence of the disease has lacked a trend to decline over the years, revealing the need to reformulate the strategies currently in place. Although governmental entities play a significant role, an active participation of livestock producers as well as industry is important.

\section{AUTHOR CONTRIBUTIONS}

LA-G wrote the manuscript and performed the literature review. DG-G participated in writing, editing, and literature review. JZ-V is joint senior author and participated in editing. AA-G is joint senior author and participated in its design, coordination, and editing. All authors helped conceive of the manuscript's message and approved the final manuscript.

\section{FUNDING}

This work was supported by Triads for Transformation (Project ID: 908), Texas A\&M University, College Station, Texas, USA. Arenas-Gamboa was supported by the grant \# K01TW009981 NIH, Fogarty.

\section{ACKNOWLEDGMENTS}

The authors would like to thank Margaret Foster (Texas A\&M University Libraries) for her contribution on literature searches, Victor Gongora (Department of Veterinary Pathobiology, Texas A\&M University) for his contribution to base map generation, and Vince Hardy (Department of Veterinary Pathobiology, Texas A\&M University) for his advice on English grammar. 


\section{REFERENCES}

1. Corbel M. Brucellosis in Humans and Animals. Geneva: World Health Organization (WHO), Food and Agriculture Organization of the United Nations (FAO) and World Organisation for Animal Health (OIE) (2006).

2. Diaz R, Casanova A, Ariza J, Moriyon I. The Rose Bengal Test in human brucellosis: a neglected test for the diagnosis of a neglected disease. PLoS Negl Trop Dis. (2011) 5:e950. doi: 10.1371/journal.pntd.0000950

3. Whatmore AM, Koylass MS, Muchowski J, Edwards-Smallbone J, Gopaul KK, Perrett LL. Extended multilocus sequence analysis to describe the global population structure of the genus brucella: phylogeography and relationship to biovars. Front Microbiol. (2016) 7:2049. doi: 10.3389/fmicb.2016.02049

4. Ducrotoy MJ, Bertu WJ, Ocholi RA, Gusi AM, Bryssinckx W, Welburn S, et al. Brucellosis as an emerging threat in developing economies: lessons from Nigeria. PLoS Negl Trop Dis. (2014) 8:e3008. doi: 10.1371/journal.pntd.0003008

5. Carvalho Neta AV, Mol JP, Xavier MN, Paixao TA, Lage AP, Santos RL. Pathogenesis of bovine brucellosis. Vet J. (2010) 184:146-55. doi: 10.1016/j.tvjl.2009.04.010

6. Olsen SC, Palmer MV. Advancement of knowledge of Brucella over the past 50 years. Vet Pathol. (2014) 51:1076-89. doi: 10.1177/0300985814540545

7. Poester F, Samartino L, Santos R. Pathogenesis and pathobiology of brucellosis in livestock. Rev Sci Tech. (2013) 32:105-15. doi: 10.20506/rst.32.1.2193

8. Franc KA, Krecek RC, Hasler BN, Arenas-Gamboa AM. Brucellosis remains a neglected disease in the developing world: a call for interdisciplinary action. BMC Public Health. (2018) 18:125. doi: 10.1186/s12889-017-5016-y

9. Dean AS, Crump L, Greter H, Hattendorf J, Schelling E, Zinsstag J. Clinical manifestations of human brucellosis: a systematic review and meta-analysis. PLoS Negl Trop Dis. (2012) 6:e1929. doi: 10.1371/journal.pntd.0001929

10. Boschilori M, Foulongne V, O'Callaghan D. Brucellosis: a worldwide zoonosis. Curr Opin Microbiol. (2001) 4:58-64. doi: 10.1016/S1369-5274(00)00165-X

11. López P. Estudio descriptivo de la presentación de brucelosis humana en Colombia desde 2000 hasta 2012. Rev Med Vet. (2014) 28:67-79. doi: $10.19052 / \mathrm{mv} .3182$

12. Mattar S, Tique V, Miranda J, Montes E, Garzon D. Undifferentiated tropical febrile illness in Cordoba, Colombia: not everything is dengue. J Infect Public Health. (2017) 10:507-12. doi: 10.1016/j.jiph.2016.09.014

13. Cardenas L, Melo O, Casal J. Evolution of bovine brucellosis in Colombia over a 7-year period (2006-2012). Trop Anim Health Prod. (2018) 50:19-27. doi: 10.1007/s11250-017-1395-4

14. Romero Y. Incidencia del PIB agropecuario en el PIB nacional Evolución y transformación. Rev Ges Des. (2011) 8:49-60. doi: 10.21500/01235834.1832

15. WorldBankGroup. Agricultura, Valor Agregado (\% del PIB). (2019). Available online at: https://datos.bancomundial.org/indicador/NV.AGR.TOTL.ZS? end=2017\&locations $=$ CO\&start $=$ 1999\&year_low_desc $=$ false

16. Departamento Administrativo Nacional de Estadística DANE. Producto Interno Bruto (PIB)-IV Trimestre de 2018/Boletín técnico. (2019). Available online at: https://www.dane.gov.co/files/investigaciones/boletines/pib/bol_ PIB_IVtrim18.pdf

17. Instituto Colombiano Agropecuario (ICA). Censo Pecuario Nacional 2017. Available online at: https:/www.ica.gov.co/areas/pecuaria/servicios/ epidemiologia-veterinaria/censos-2016/censo-2017.aspx

18. Federación Colombiana de Ganaderos FEDEGAN. Cifras de Referencia del Sector Ganadero Colombiano. Bogota, DC: FEDEGAN (2017)

19. Carulla JE, Ortega E. Sistemas de producción lechera en Colombia: Retos y oportunidades. Arch Latinoam Prod Anim. (2016) 24:83-7. Available online at: https://dialnet.unirioja.es/servlet/articulo? codigo $=6801863$

20. Lerner AM, Zuluaga AF, Chara J, Etter A, Searchinger T. Sustainable cattle ranching in practice: moving from theory to planning in Colombia's livestock sector. Environ Manage. (2017) 60:176-84. doi: 10.1007/s00267-017-0902-8

21. Reyes GA. The Dairy Industry in Colombia. Columbus: CFAES Ohio State University Extension (2013).

22. Federación Colombiana de Ganaderos FEDEGAN. Cifras de Referencia del Sector Ganadero Colombiano. Bogota, DC: FEDEGAN (2019).

23. Instituto Colombiano Agropecuario (ICA). Censo Pecuario Nacional 2016. Available online at: https://www.ica.gov.co/getdoc/8232c0e5-be97-42bdb07b-9cdbfb07fcac/censos-2008.aspx
24. Van-Haandel B. Colombia's Pig Sector Facing Challenges. (2016). Available online at: https://www.pigprogress.net/Finishers/Articles/2016/2/Colombiaspig-industry-faces-disease-import-challenges-2750334W/

25. Acero-Plazas VM. El bienestar animal en sistemas productivos de ovinos-caprinos en Colombia. Spei Domus. (1969) 10:57-62. doi: $10.16925 /$ sp.v10i21.918

26. Cortés HA. Situación del Recurso Ovino y Caprino en Colombia. Ministerio de Agricultura (2010). Available online at: https://sioc.minagricultura.gov. co/OvinoCaprina/Documentos/005\%20-\%20Documentos\%20Técnicos/ Situacion\%20Recursos\%20Ovino\%20-\%20Caprino.pdf

27. Orozco V, Hidalgo P. Sector Ovino y Caprino. (2015). Available online at: https://sioc.minagricultura.gov.co/OvinoCaprina/Documentos/002\%20\%20Cifras\%20Sectoriales/2015\%20Junio.pdf

28. Asociación Colombiana de Criadores de Búfalos. Por Rentabilidad Crece la Cría de Búfalos en Colombia. (2018). Available online at: http://asobufalos. com/5-ventajas-de-criar-bufalos-en-colombia/

29. Calderón A, Tique V, Ensuncho CF, Rodríguez V. Seroprevalencia de Brucella abortus en Bufalos de agua (Bubalus bubalis) en el municipio de Lorica, Córdoba. Rev UDCA Act Div Cient. (2010) 13:125-32. Available online at: http://www.scielo.org.co/pdf/rudca/v13n2/v13n2a15.pdf

30. Mora J, Calderón JC, Gómez SM. El componente pecuario en fincas campesinas de la ecoregión cafetera del departamento del Tolima (Colombia). Luna Azul. (2011) 32:16-31. Available online at: https://www.academia.edu/ 32571525/El_Componente_Pecuario_en_Fincas_Campesinas_De_La_ Ecorregi\%C3\%B3n_Cafetera_Del_Departamento_Del_Tolima_Colombia

31. Food and Agriculture Organization of the United Nations (FAO). Livestock Production in Latin America and the Caribbean. (2019). Available online at: http://www.fao.org/americas/prioridades/produccion-pecuaria/en/

32. Valencia M, Guzmán M. Brucelosis Humana. Bogota, DC: Monografía $\mathrm{N}^{\circ} 1$ : Instituto Nacional de Salud I.N.S. (1987).

33. Herrera AA. Epizootic abortion and the presence of agglutinins in milk consumed in Bogota (Colombia). Rev Med Vet. (1935) 6:4-19.

34. Torres Higuera LD, Jimenez Velasquez SDC, Rodriguez Bautista JL, Patino Burbano RE. Identification of Brucella abortus biovar 4 of bovine origin in Colombia. Rev Argent Microbiol. (2018) 51:221-8. doi: 10.1016/j.ram.2018.08.002

35. Ortiz L, Muskus C, Sánchez M, Olivera M. Identification of Brucella canis Group 2 in colombian kennels. Rev Colomb Ciencias Pecuarias. (2012) 25:6159. Available online at: http://www.scielo.org.co/scielo.php?script=sci_arttext\& pid=S0120-06902012000400009

36. Díaz OL, Mendoza E, Linares C, Gasca HH, Jaramillo DC, Rodríguez DF, et al. Colombia, Sanidad Animal 2015. Bogota, DC: Instituto Colombiano Agropecuario (ICA). Instituto Colombiano Agropecuario (ICA) (2017).

37. Instituto Colombiano Agropecuario (ICA). Resolución 00007231: Por Medio de la Cual se Establecen las Medidas Sanitarias Para la Prevención, Control y Erradicación de Brucellosis en las Especies Bovina, Bufalina, Ovina, Caprina, Porcina y Equina en Colombia. (2017). Available online at: https://www.ica. gov.co/areas/pecuaria/servicios/convocatoria-publica-de-autorizacion-enel-diagnos/resolucion-7231-de-2017.aspx

38. Monroy W. Reunión de Consulta de Expertos de la OPS/OMS Sobre Vacunas y Estrategias de Vacunación en los Programas de Control y Erradicación de la Brucellosis. Rio de Janeiro: Centro Panamericano de Fiebre Aftosa (1999). p. $1-139$.

39. Uzal FA, Samartino L, Schurig G, Carrasco A, Nielsen K, Cabrera RF, et al. Effect of vaccination with brucella abortus strain RB51 on heifers and pregnant cattle. Vet Res Commun. (2000) 24:143-51. doi: 10.1023/A:1006468713614

40. Dorneles EM, Sriranganathan N, Lage AP. Recent advances in Brucella abortus vaccines. Vet Res. (2015) 46:76. doi: 10.1186/s13567-0150199-7

41. Stevens MG, Olsen SC, Palmer MV, Pugh GWJ. Immune responses and resistance to brucellosis in mice vaccinated orally with Brucella abortus. RB51. Infect Inmun. (1996) 64:4534-41.

42. Olsen SC, Stoffregen WS. Essential role of vaccines in brucellosis control and eradication programs for livestock. Expert Rev Vaccines. (2005) 4:915-28. doi: $10.1586 / 14760584.4 .6 .915$ 
43. World Organisation for Animal Health (OIE). Chapter 2.4.3: Bovine brucellosis. In: OIE Terrestrial Manual. Paris: World Organisation for Animal Health (2012). p. 616-50.

44. Federación Colombiana de Ganaderos FEDEGAN. Programa de Prevención, Control y Erradicación de la Brucelosis Bovina 2019 Available online at: https://www.fedegan.org.co/programas/programa-de-prevencioncontrol-y-erradicacion-de-la-brucelosis-bovina.

45. Instituto Colombiano Agropecuario (ICA). Resolución 3714: Por la Cual se Establecen las Enfermedades de Declaración Obligatoria en Colombia. (2015). Available online at: https://www.icbf.gov.co/cargues/avance/docs/resolucion_ ica_3714_2015.htm

46. World Organization for Animal Health (OIE). OIE-Listed Diseases, Infections and Infestations in Force. (2019). Available online at: http://www.oie.int/en/ animal-health-in-the-world/oie-listed-diseases-2019/

47. Cardenas L, Awada L, Tizzani P, Caceres P, Casal J. Characterization and evolution of countries affected by bovine brucellosis (1996-2014). Transbound Emerg Dis. (2019) 66:1280-90. doi: 10.1111/tbed.13144

48. Zhang N, Huang D, Wu W, Liu J, Liang F, Zhou B, et al. Animal brucellosis control or eradication programs worldwide: a systematic review of experiences and lessons learned. Prev Vet Med. (2018) 160:105-15. doi: 10.1016/j.prevetmed.2018.10.002

49. Instituto Colombiano Agropecuario (ICA). Resolución 13170: Por Medio de la Cual se Establecen los Requisitos y Procedimientos Para el Registro de Autorización de Organismos de Inspección Para la Ejecución de Actividades en el Programa Nacional de Prevención, Control y Erradicación de la Brucelosis y/o en el Programa Nacional de Prevención, Control y Erradicación de la Tuberculosis Bovina. (2016). Available online at: https://www.ica.gov.co/areas/ pecuaria/servicios/enfermedades-animales/resolucion-13170-de-2016.aspx

50. Instituto Colombiano Agropecuario (ICA). Cuarentena de Animales Para Importación. (2019). Available online at: https://www.ica.gov.co/importacion$\mathrm{y}$-exportacion/procedimientos-importacion/cuarentena.aspx

51. Osorio FJ, Patiño A, Linares C, Romero LA, Ortiz J, Reina JF, et al. Colombia, Sanidad Animal 2012. Bogota, DC: Instituto Colombiano Agropecuario (ICA). Instituto Colombiano Agropecuario (ICA) (2013).

52. Instituto Colombiano Agropecuario (ICA). Programa Nacional de Prevención y Control de la Brucellosis Bovina. Subgerencia de Protección Animal. Bogota, DC: Dirección Técnica de Sanidad Animal (2019).

53. Díaz OL, Orjuela JE, Ortiz J, Patiño A, Linares C, González PM. Colombia, Sanidad Animal 2009. Bogota, DC: Instituto Colombiano Agropecuario (ICA). Instituto Colombiano Agropecuario (ICA) (2011).

54. Orjuela JE, Díaz OL, González PM, Ortiz J, Monrroy WE, Patiño A. Colombia, Sanidad Animal 2008. Bogota, DC: Instituto Colombiano Agropecuario (ICA). Intituto Colombiano Agropecuario (ICA) (2009).

55. Orjuela JE, Díaz OL, González PM, Ortiz J, Monrroy WE. Colombia, Sanidad Animal 2007. Bogota, DC: Instituto Colombiano Agropecuario (ICA). Instituto Colombiano Agropecuario (ICA) (2009).

56. Orjuela JE, Díaz OL, González PM, Ortiz J, Monrroy WE. Colombia, Sanidad Animal 2006. Bogota, DC: Instituto Colombiano Agropecuario (ICA). Instituto Colombiano Agropecuario (ICA) (2007).

57. Orjuela JE, Díaz OL, González PM, Ortiz J, Monrroy WE. Colombia, Sanidad Animal 2005. Bogota, DC: Instituto Colombiano Agropecuario (ICA). Instituto Colombiano Agropecuario (ICA) (2007).

58. Díaz OL, Ortiz J, Reina JF, Patiño A, Linares C, González PM, et al. Colombia, Sanidad Animal 2011. Bogota, DC: Instituto Colombiano Agropecuario (ICA). Instituto Colombiano Agropecuario (ICA) (2014).

59. Díaz OL, Ortiz J, Reina JF, Patiño A, Linares C, González PM. Colombia, Sanidad Animal 2010. Bogota, DC: Instituto Colombiano Agropecuario (ICA). Instituto Colombiano Agropecuario (ICA) (2012).

60. Díaz OL, Mendoza E, Linares C, Gasca HH, Jaramillo DC, Barón JP, et al. Colombia, Sanidad Animal 2014. Bogota, DC: Instituto Colombiano Agropecuario (ICA). Instituto Colombiano Agropecuario (ICA) (2017).

61. Araujo AJ, Patiño A, Linares C, Santander A, Barón JP, Botero A. Colombia, Sanidad Animal 2013. Bogota, DC: Instituto Colombiano Agropecuario (ICA). Instituto Colombiano Agropecuario (ICA) (2015).

62. Ministerio de Agricultura y Desarrollo Rural. Resolución 000017: Por la Cual se Establece el Sistema de Pago de Leche Cruda al Proveedor. (2012). Available online at: https://www.minagricultura.gov.co/ministerio/
direcciones/Documents/d.angie/Res\%20\%20000017\%20de\%202012.pdf\# search=resolucion $\% 2017 \% 20 \mathrm{de} \% 202012$

63. Cardenas L, Canas-Alvarez JJ, Vazquez A, Boixadera E, Casal J. Analysis of domestic animal movements in Colombia (2006-2014) and their possible influence on the bovine brucellosis spread. Trop Anim Health Prod. (2019) 51:383-8. doi: 10.1007/s11250-018-1701-9

64. Fevre EM, Bronsvoort BM, Hamilton KA, Cleaveland S. Animal movements and the spread of infectious diseases. Trends Microbiol. (2006) 14:125-31. doi: 10.1016/j.tim.2006.01.004

65. Cipullo RI, Grisi-Filho JHH, Dias RA, Ferreira F, Ferreira Neto JS, Gonçalves VSP, et al. Cattle movement network, herd size, and bovine brucellosis in the State of Mato Grosso, Brazil. Semin Ciências Agrárias. (2016) 37:3777. doi: 10.5433/1679-0359.2016v37n5Supl2p3777

66. Contexto Ganadero. Polfa Desarticula Banda que Introducía 4.200 Reses de Ganado de Contrabando. News (2018). Available online at: https://www. contextoganadero.com/regiones/polfa-desarticula-banda-que-introducia4200-reses-de-ganado-de-contrabando

67. Federación Colombiana de Ganaderos FEDEGAN. 4 Millones de Bovinos Entraron de Contrabando Entre 2016 y Parte de 2018. Lafaurie (2019). Available online at: https://www.fedegan.org.co/noticias/4-millones-debovinos-entraron-de-contrabando-entre-2016-y-parte-de-2018-lafaurie

68. Rodríguez J, Llano M, Fonseca B. Estudio Sectorial Sobre la Producción Cárnica Bovina en la Región del Caribe. Contraloría General de la República (2018). Available online at: https://www.contraloria.gov.co/documents/ 20181/996701/2018\$+\$ESD+\$Carne\$+\$bovina\$+\$2018\$+\$.pdf/156ff515af06-4047-b5a1-886da96ff09d?version=1.0

69. Diaz S. Factores de riesgo asociados a la seroprevalencia de brucelosis bovina en Colombia. (MSc thesis), Universidad Nacional de Colombia (2019).

70. Instituto Colombiano Agropecuario (ICA). Resolución 00030392: Por Medio de la Cual se Declaran en Cuarentena por Brucelosis Bovina los Minucipios de Santa Rosa de Osos, San Pedro de los Milagros, Belmira, Enterrios, Donmatias, Angostura, Yarumal, San Jose de la Montaña, San Andres del Cuerquia y las Veredas Charco Verde, Cuartas, La Union, El Tambo, El Carmelo, Jalisco los Alvarez, La Palma, Sabanalarga, Las Meneses y La China del municipio de Bello, ubicados en el departamento de Antioquia. (2018). Available online at: https://www.ica.gov.co/getattachment/8b0be33a4893-4185-8404-7295b986026e/R30392.aspx

71. Motta PA, Herrera W, Londoño M, Rojas EP, Rivera LG. Prevalencia de brucelosis (Brucella_spp) en bovinos del minicipio de San Vicente del Caguán, Caquetá, Colombia. Vet Zoot. (2018) 12:1-9. doi: 10.17151/vetzo.2018. 12.2.1

72. Oviedo-Pastrana M, Brunal-Tachack E, Doria-Ramos M, Oviedo-Socarras T. Análisis de indicadores epidemiológicos: Brucelosis bovina en la Costa Atlántica y Antioquia-Colombia, 2005-2013. Rev MVZ Córdoba. (2017) 22:6034. doi: 10.21897/rmvz.1073

73. Arenas NE, Abril DA, Valencia P, Khandige S, Soto CY, Moreno V. Screening food-borne and zoonotic pathogens associated with livestock practices in the Sumapaz region, Cundinamarca, Colombia. Trop Anim Health Prod. (2017) 49:739-45. doi: 10.1007/s11250-017-1251-6

74. Tique V, González M, Mattar S. Seroprevalencia de Brucella abortus. en bovinos del departamento de Córdoba. Rev UDCA Act Div Cient. (2009) 12:51-9. Available online at: http://www.scielo.org.co/scielo.php? script=sci_arttext\&pid=S0123-42262009000200006

75. Calderón A, Angulo LA, Tique V, Rodríguez VC, Ensuncho CF. Seroprevalencia de Brucelosis Bovina en dos Localidades del Caribe Colombiano. Orinoquí. (2015) 19:203-9. doi: 10.22579/2011 2629.334

76. Camacho R, Carvajal LY, Castellanos YZ, Díaz WF, Vásquez MC. Presence of IgG antibodies against reproductive infections in breeding bulls of Magdalena Medio, Colombia. Rev Colomb Ciencias Pecuarias. (2015) 28:32330. doi: 10.17533/udea.rccp.v28n4a04

77. González M, Ríos R, Máttar S. Prevalencia de bacterias asoiadas a la infertilidad infecciosa en bovinos de Montería, Colombia. Rev MVZ Córdoba. (2007) 12:1028-35. doi: 10.21897/rmvz.423

78. Pfeiffer D, Cortes CE, Otte E, Morris RS. Management factors affecting the prevalence of Brucellosis in traditionally managed cattle herds in northern of Colombia. Acta Vet Scand. (1988) (Suppl. 84):133-5. 
79. Griffiths IB, Gallego MI, De Leon LS. Levels of some reproductive diseases in the dairy cattle of Colombia. Trop Anim Hlth Prod. (1984) 16:219-23. doi: $10.1007 / \mathrm{BF} 02265325$

80. Motta JL, Clavijo JA, Waltero I, Abeledo MA. Prevalencia de anticuerpos a Brucella abortus Leptospira sp. y Neospora caninum en hatos bovinos y bubalinos en el Departamento del Caquetá, Colombia. Rev Salud Anim. (2014) 36:80-9. Available online at: http://scielo.sld.cu/scielo.php?script=sci_ arttext\&pid=S0253-570X2014000200002

81. Tique V, Daza E, Alvarez J, Mattar S. Seroplevalencia de Brucella abortus. y ocurrencia de Brucella melitensis en caprinos y ovinos de César y Sucre. Rev UDCA Act Div Cient. (2010) 13:133-9. Available online at: http://www.scielo. org.co/pdf/rudca/v13n2/v13n2a16.pdf

82. Restrepo JG, Orrego Y, Agudelo SP, Villa BA. Incidencia de Brucella suis en cerdos de Lomarena Bolívar. Rev Med Vet Zoot. (2008) 3:51-7. Available online at: http://www.redalyc.org/pdf/3214/321428100005.pdf

83. Lucero NE, Ayala SM, Escobar GI, Jacob NR. Brucella isolated in humans and animals in Latin America from 1968 to 2006. Epidemiol Infect. (2008) 136:496-503. doi: 10.1017/S0950268807008795

84. Osejo AF, Chilangua LF, Astudillo D, Canaval ZS, Delgado MF. Prevalencia de Brucelosis humana en trabajadores de mataderos en el departamento del Cauca-Colombia. Rev Facul Ciencias Salud Univ Cauca. (2005) 7:8-12. Available online at: https://revistas.unicauca.edu.co/index.php/rfcs/article/ view/912

85. World Health Organization (WHO). The Control of Neglected Zoonotic Diseases. Community-Based Interventions for Prevention and Control. Report of the third conference organized with ICONZ, DFID-RIU, Gates Foundation, SOS, EU, TDR and FAO With the Participation of ILRI and OIE (2010).

86. Segovia A. The Relationships Between Food Security and Violent Conflicts: The Case of Colombia. Rome: Food and Agriculture Organization of the United Nations (FAO) (2017). p. 1-44.

87. Perfeti JJ. Crisis y Pobreza Rural en América Latina: el Caso de Colombia. Documento de Trabajo $\mathrm{N}^{\circ}$ 43. Programa Dinámicas Territoriales Rurales. Santiago: Rimisp (2009).

88. Ragan VE. The Animal and Plant Health Inspection Service (APHIS) brucellosis eradication program in the United States. Vet Microbiol. (2002) 90:11-8. doi: 10.1016/S0378-1135(02)00240-7

89. Instituto Colombiano Agropecuario (ICA). Resolución 1332: Por Medio de la Cual se Actualizan las Medidas Sanitarias Para la Prevención, el Control y la Erradicación de la Brucelosis en las Especies Bovina y Bufalina de Colombia. (2013). Available online at: https://www.ica.gov.co/normatividad/normas$\mathrm{ica} /$ resoluciones- oficinas-nacionales/resoluciones-derogadas/resol-1332-de2013.aspx

90. Instituto Colombiano Agropecuario (ICA). Resolución 1192: Por la Cual se Establecen Medidas Sanitarias Para la Prevención, el Control y la Erradicación de Brucelosis en las Especies Bovina, Bubalina, Caprina, Ovina y Porcina en la República de Colombia. (2008). Available online at: https://www.ica.gov.co/ getattachment/3edf9d2a-9402-45ce-a5c9-5e1b85e94e9a/R1192.aspx
91. Instituto Colombiano Agropecuario (ICA). Resolución 840: Por Medio de la Cual se Establecen Medidas Sanitarias Para la Prevención, el Control y la Erradicación de la Brucelosis en las Especies Bovina, Bufalina, Caprina, Ovina y Porcina en Colombia. (2011). Available online at: https://www.ica.gov.co/ normatividad/normas-ica/resoluciones-oficinas-nacionales/resolucionesderogadas/resolucion-840-de-2011.aspx

92. Instituto Colombiano Agropecuario (ICA). Resolución 550: Por la Cual se Establecen Medidas Sanitarias Para el Control de la Brucelosis en las Especies Bovina, Bubalina, Caprina y Ovina en la República de Colombia. (2006). Available online at: https://www.ica.gov.co/getattachment/4ff425ffbae8-432c-9266-5981652761fd/R0550.aspx

93. Instituto Colombiano Agropecuario (ICA). Vacunación Contra Brucellosis Bovina. (2019). Available online at: https://www.ica.gov.co/areas/pecuaria/ servicios/enfermedades-animales/brucelosis-bovina-1/vacunacionbrucelosis.aspx

94. Cardenas L, Peña M, Melo O, Casal J. Risk factors for new bovine brucellosis infections in Colombian herds. BMC Vet Res. (2019) 15:81. doi: 10.1186/s12917-019-1825-9

95. Dalrymple M. Model for assessing the risk of introducing brucellosis into a brucellosis-free area. Rev Sci Tech Off Int Epiz. (1993) 12:1175-86. doi: 10.20506/rst.12.4.735

96. Arenas NE, Moreno V. Estudio económico de la infección por Brucella abortus en el ganado bovino de la región del Sumapaz, Cundinamarca. Rev Med Vet Zoot. (2016) 63:218-28. doi: 10.15446/rfmvZ.v63n3.62751

97. Holveck JC, Ehrenberg JP, Ault SK, Rojas R, Vasquez J, Cerqueira MT, et al. Prevention, control, and elimination of neglected diseases in the Americas: pathways to integrated, inter-programmatic, inter-sectoral action for health and development. BMC Public Health. (2007) 7:6. doi: 10.1186/1471-2458-7-6

98. García DG, Orozco MR, Suarez DM, Perry S. Mejoramiento Tecnológico Participativo. Una Guía Para Construir Procesos de Innovación Tecnológica con Comunidades Rurales. Manual Para Facilitadores. Bogota, DC: Corporación PBA (2011). p. 1-48.

99. Lounes N, Cherfa MA, Le Carrou G, Bouyoucef A, Jay M, Garin-Bastuji B, et al. Human brucellosis in Maghreb: existence of a lineage related to socio-historical connections with Europe. PLoS ONE. (2014) 9:e115319. doi: 10.1371/journal.pone.0115319

Conflict of Interest: The authors declare that the research was conducted in the absence of any commercial or financial relationships that could be construed as a potential conflict of interest.

Copyright (C) 2019 Avila-Granados, Garcia-Gonzalez, Zambrano-Varon and ArenasGamboa. This is an open-access article distributed under the terms of the Creative Commons Attribution License (CC BY). The use, distribution or reproduction in other forums is permitted, provided the original author(s) and the copyright owner(s) are credited and that the original publication in this journal is cited, in accordance with accepted academic practice. No use, distribution or reproduction is permitted which does not comply with these terms. 